DE

M E D I C I N A

T R O P I C A L

$\mathrm{DE}$

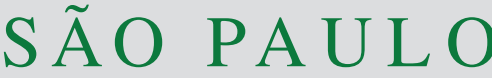

JOURNAL OF THE SÃO PAULO INSTITUTE OF TROPICAL MEDICINE

'Universidade de São Paulo, Instituto de Medicina Tropical de São Paulo, Laboratório de Investigação Médica (LIM 46), São Paulo, São Paulo, Brazil

2Universidade de São Paulo, Instituto de Medicina Tropical de São Paulo, Laboratório de Soroepidemiologia e Imunologia, São Paulo, São Paulo, Brazil

Correspondence to: Beatriz Araujo Oliveira Universidade de São Paulo, Instituto de Medicina Tropical de São Paulo, Laboratório de Investigação Médica (LIM 46), Av. Dr. Enéas Carvalho de Aguiar, 470, CEP 05403-000, São Paulo, SP, Brazil Tel: +551130617011

E-mail: Beatriz_oliveira@usp.br

Received: 27 May 2020

Accepted: 18 June 2020

\section{SARS-CoV-2 and the COVID-19 disease: a mini review on diagnostic methods}

\author{
Beatriz Araujo Oliveira ${ }^{\circledR 1}$, Lea Campos de Oliveira ${ }^{(1)}$, Ester Cerdeira \\ Sabino ${ }^{(1}$, Thelma Suely Okay ${ }^{\circledR 2}$
}

\section{ABSTRACT}

Coronavirus disease 2019 (COVID-19) is an infectious disease initially reported in China and currently worldwide dispersed caused by a new coronavirus (SARS-CoV-2 or 2019-nCoV) affecting more than seven million people around the world causing more than 400 thousand deaths (on June $8^{\text {th }}, 2020$ ). The diagnosis of COVID-19 is based on the clinical and epidemiological history of the patient. However, the gold standard for COVID-19 diagnosis is the viral detection through the amplification of nucleic acids. Although the quantitative Reverse-Transcription Polymerase Chain Reaction (RT-PCR) has been described as the gold standard for diagnosing COVID-19, there are several difficulties involving its use. Here we comment on RT-PCR and describe alternative tests developed for the diagnosis of COVID-19.

KEYWORDS: COVID-19. SARS-CoV-2. 2019-nCoV. RT-PCR. Serological methods. Immunochromatography.

\section{INTRODUCTION}

In December 2019, an outbreak of pneumonia of unknown etiology was reported in Hubei province, Wuhan municipality, China. In January 2020, the etiologic agent was isolated and described by the Chinese government as a new coronavirus (SARS-CoV-2 or 2019-nCoV) ${ }^{1-4}$.

SARS-CoV2 is one of seven human-infecting coronaviruses identified so far. It is a single strand positive sense RNA virus (+)ssRNA belonging to the $\beta$-coronavirus lineage $\mathrm{B}^{1-3}$. In March 2020, the World Health Organization (WHO) declared the disease COVID-19, caused by SARS-CoV2, as a pandemic and according to WHO, there were more than seven million confirmed cases worldwide and more than 400 thousand deaths (on June $\left.8^{\text {th }}, 2020\right)^{1,5}$.

SARS-CoV-2 genome codes for a polyprotein (ORF1ab) involved in the transcription and replication of the viral RNA, four structural proteins: $\mathrm{E}$ for envelope; $\mathrm{M}$ for membrane; $\mathrm{N}$ for nucleocapsid that is necessary for the viral synthesis and the $S$ protein for Spike, that allows the entry and the infection of the host cell, in addition to five accessory proteins (ORF3a, ORF6, ORF7a, ORF8 and ORF10) $)^{1,3,6,7}$.

The viral S protein binds to the human ACE2 receptor, causing conformational changes in the coronavirus and allowing its fusion to the host cell membrane. The process of entering the cell requires the action of the TMPRSS2 protease, which regulates the cleavage of the $S$ protein ${ }^{6,8}$.

The clinical presentation of COVID-19 disease comprises a broad range of unspecified symptoms, such as fever, dry cough, dyspnea, headache, sputum 
production, hemoptysis, myalgia, fatigue, nausea, vomiting, diarrhea and abdominal pain ${ }^{1,3,4,9,10}$. Loss of smell and taste were not commonly described in China, but have been reported more recently as an early clinical marker of COVID-19 11,12 .

COVID-19 patients may be classified as asymptomatic or symptomatic, and the symptoms can vary from mild to severe and critical $^{1,3,13}$. The severe acute respiratory syndrome (SARS) is more common among people with risk factors, such as advanced age, smoking and those with associated comorbidities (diabetes, hypertension, cardiovascular disease, obesity, chronic lung disease, kidney diseases) $)^{1,4,14}$.

Once humans are infected, they begin to transmit the virus through droplets, sneezing, aerosols ${ }^{1,4,10}$. Some findings in the literature suggest that patients with none or only mild symptoms can release large amounts of viruses during the initial stage of the infection ${ }^{1,10,15,16}$, favoring the rapid spread of the virus ${ }^{1,10,14,17,18}$. However, Pan et al. ${ }^{19}$, in a study with 26 asymptomatic patients noticed that transmission by asymptomatic patients was less frequent than by symptomatic ones, suggesting that asymptomatic patients are less infectious.

The disease incubation period varies from 3-14 days, with an initial estimated basic reproduction number (R0) of 2.2, that is, each patient transmits the infection to other 2.2 individuals $^{1,4}$. However, with the accumulated experience and higher numbers of patients in different countries, mathematical and epidemiological studies estimated COVID-19 R0 varying from 1.4 to $6.47^{2,10,17}$, depending on the isolation and quarantine, as well as other control measures ${ }^{10,16}$.

Due to the high transmission rate of SARS-CoV2, specific measures are urgently needed to contain the pandemic, such as the improvement of diagnostic methods for the detection of asymptomatic and mildly symptomatic patients during the early phases of the disease. In this mini review, we summarize and discuss the diagnostic methods currently available $1^{1,2,14}$.

\section{Laboratory methods}

The diagnosis of COVID-19 is based on the clinical and epidemiological history of the patient, as well as on ancillary exams findings, for instance the chest X-ray and especially the chest tomography (CT-scan) revealing the characteristic images of ground glass, that were also seen in asymptomatic patients. However, the gold standard for COVID-19 diagnosis is through the analysis of nucleic acids, that is, the demonstration of SARS-CoV2 RNA in respiratory samples ${ }^{9,19-21}$.

\section{Non-specific exams}

Laboratory findings include leukopenia and lymphopenia in $80 \%$ of the cases, depletion of CD4 and CD8 lymphocytes, in addition to mild thrombocytopenia. Some authors have also suggested changes in the neutrophil/lymphocyte ratio in the severe disease progression of COVID-19 patients $^{1,10,22}$.

Increased inflammatory markers have also been described in COVID-19: lactate dehydrogenase (LDH), erythrocyte sedimentation rate (ESR), C-reactive protein (CRP), aspartate aminotransferase (ASAT), troponin, ferritin, creatine kinase (CK) and D-dimer, in addition to the extended prothrombin time ${ }^{1,10,22}$.

Severely ill patients may have high levels of cytokines IL2, IL4, IL6, IL7, IL10 and tumor necrosis factor $(\mathrm{TNF})^{1,10,22}$. In patients with the severe acute respiratory syndrome, the so-called cytokines storms was observed, with the release of the previously mentioned cytokines in addition to others, such as CCL2, CCL3, CCL5, CXCL10, leading to multiple organs failure and eventually to death $^{23-25}$.

\section{The quantitative Reverse-Transcription Polymerase Chain Reaction (RT-PCR)}

In January 2020, the novel coronavirus was isolated from Wuhan's patients providing information on the viral genetic sequencing, available at the Global Initiative on Sharing All Influenza Data - GISAID, allowing the development of the specific diagnostic methods for COVID-19 through quantitative Reverse-Transcription Polymerase Chain Reaction (RT-PCR) system, i.e, quantitative Real Time amplifications preceded by RNA extraction from the nasopharyngeal and oropharyngeal secretions, followed by a reverse transcription step to convert RNA into complementary DNA (cDNA) that will undergo amplification. The RT-PCRs that have been applied to COVID-19 diagnosis contain fluorescent probes that will recognize and hybridize to segments of the amplification products, increasing the assays specificity ${ }^{1,26,27}$.

The RT-PCR is the gold standard for the confirmation of COVID-19 disease in upper respiratory samples (nasopharyngeal and oropharyngeal secretion). Several RT-PCR protocols were released by WHO to provide a suitable diagnosis, help testing populations and contribute to controlling the spread of the disease (Table 1) ${ }^{1,28}$.

The RT-PCR protocol designed by the Institut Pasteur (France) showed excellent results in comparison with the protocol from Charité (Germany), considered the reference RT-PCR, reaching nearly $95 \%$ assertiveness in samples containing around 100 copies of SARS-CoV-2 genome. 
In this protocol, two targets from the RNA-dependent RNA Polymerase (RdRP) gene of SARS-CoV-2 were evaluated separately (nCoV-IP2 and 4 - Table 1), and then the primers were combined in multiplex RT-PCR assays resulting in the detection of samples containing 10 copies of the virus genome ${ }^{29}$. The specificity was evaluated using samples containing other respiratory viruses $(\mathrm{H} 1 \mathrm{~N} 1, \mathrm{H} 3 \mathrm{~N} 2$, B-Victoria, B-Yamagata, influenza C, RSV A and B, hBoV, hPIV, hMPV, HRV/enterovirus, adenovirus, HKU1, OC43, 229E and NL63) and none of them was detected with the RdRp gene/nCoV-IP2 and $4^{29}$.

Although RT-PCR has been described as the gold standard for diagnosing COVID-19, there are several difficulties involving its use ${ }^{1,10,23,28,30}$. The RT-PCR kit distributed by China's CDC was designed to detect the nucleocapsid (N) and the Open Reading Frame ORF1ab of SARS- CoV-2 genome, and the infection is confirmed when both markers are amplified (Table 1). However, it is not infrequent that the results are inconsistent due to the amplification of only one of the targets ${ }^{10,23}$.

One of the bottlenecks related to RT-PCR for the diagnosis of COVID-19 is the incorrect collection and processing of samples. Some studies suggest that samples obtained from the upper respiratory tract (bottom of the nostrils and the oropharynx $)^{1,9,10}$ are optimal clinical samples due the high viral copy number in the respiratory tract. In addition to oral and nasal swabs, viral load levels can be detected in the gastrointestinal tract and eventually in blood samples, however in lower amounts ${ }^{27,28,31}$.

A study performed by Yang et al. ${ }^{32}$, using different samples (throat swabs, nasal swabs, sputum and broncho alveolar lavage fluid-BALF) collected in different period of times ( 0 to 7,8 to 14 , and more than 15 days after the onset of disease) evidenced that except for BALF, sputum samples presented the highest positivity rate $(74.4 \%$ and $88.9 \%$ ), followed by nasal swabs (53.6\% and $73.3 \%$ ) from severely and mildly symptomatic patients in the first 14 days after the onset of disease, respectively. After 15 days of the onset of disease, sputum and nasal swabs presented lower positive rates $(42.9 \% \text { and } 61.1 \% \text {, respectively })^{32,33}$. BALF was considered important for monitoring and diagnosing severe cases, while throat swabs presented the lowest positivity among the samples ${ }^{32,33}$.

A report of two Korean patients found different viral load kinetics suggesting variations among infected people. In the first patient the virus was detected between two and three days after the onset of symptoms in both, the lower and the upper respiratory tract. However, viral load levels

Table 1 - Description of the most used RT-PCR for diagnosing SARS-Cov-2.

\begin{tabular}{|c|c|c|c|}
\hline Institution/ country & Primer ID & Method & Findings \\
\hline $\begin{array}{l}\text { China's CDC - } \\
\text { China }^{29,56}\end{array}$ & ORF1ab, E and N & $\begin{array}{l}\text { Three singleplex RT-PCR using } \\
\text { fluorescent-labeled probes }\end{array}$ & $\begin{array}{l}\text { Lowest detection limit of ORF1ab was } 203 \\
\text { copies } / \mathrm{mL} \\
\text { Lowest detection limit of } \mathrm{E} \text { gene was } 664 \\
\text { copies } / \mathrm{mL} \\
\text { Lowest detection limit of } \mathrm{N} \text { gene was } 667 \\
\text { copies } / \mathrm{mL}\end{array}$ \\
\hline $\begin{array}{l}\text { Institut Pasteur - } \\
\quad \text { France }^{29}\end{array}$ & $\begin{array}{l}\text { RdRp gene/nCoV_IP2 } \\
\text { RdRp gene/nCoV_IP4 }\end{array}$ & $\begin{array}{l}\text { Two singleplex RT-PCR or } \\
\text { one multiplex RT-PCR with } \\
\text { fluorescent-labeled probes }\end{array}$ & $\begin{array}{l}95 \% \text { assertiveness in samples containing } \\
100 \text { viral copies } \\
\text { The multiplex RT-PCR detects } 10 \text { viral copies } \\
\text { No cross-reactivity with other viruses }\end{array}$ \\
\hline CDC - USA 29,57 & $\begin{array}{l}\text { 2019-nCoV_N1 } \\
2019-n C o V \_N 2 \\
2019-n C o V \_N 3\end{array}$ & $\begin{array}{l}\text { Three singleplex RT-PCR using } \\
\text { fluorescent-labeled probes }\end{array}$ & $\begin{array}{l}95 \% \text { assertiveness in samples containing } \\
10^{0,5} \text { RNA copies/ } \mu \mathrm{L} \text { using automatic RNA } \\
\text { extraction and } 10^{\circ} \text { RNA copies/ } \mu \mathrm{L} \text { using manual } \\
\text { RNA extraction }\end{array}$ \\
\hline Charité - Germany ${ }^{29,58}$ & $\begin{array}{l}\text { RdRP_SARSr } \\
\text { E_Sarbeco }\end{array}$ & $\begin{array}{l}\text { Two singleplex RT-PCR, the } \\
\text { screening made by the E gene } \\
\text { amplification confirmed by } \\
\text { RdRP }\end{array}$ & $\begin{array}{l}\text { Lowest detection limit of RdRp and E_Sarbeco } \\
3.8 \text { and } 5.2 \text { copies/reaction, respectively }\end{array}$ \\
\hline HKU - Hong Kong ${ }^{29,59}$ & $\begin{array}{l}\text { ORF1b-nsp14 } \\
\mathrm{N}\end{array}$ & $\begin{array}{l}\text { Two RT-PCR, firstly the N gene } \\
\text { amplification with fluorescent- } \\
\text { labed probe followed by } \\
\text { confirmation by amplifying the } \\
\text { ORF1b-nsp14 with fluorescent- } \\
\text { labeled probe }\end{array}$ & $\begin{array}{l}\mathrm{N} \text { gene Ct values up to } 35.43 \text { were positive } \\
\text { corresponding to } 15 \text { copies/reaction } \\
\text { ORF1b Ct values up to } 38.97 \text { were positive } \\
\text { corresponding to } 1.5 \text { copies/reaction }\end{array}$ \\
\hline $\begin{array}{l}\text { National Institute of } \\
\text { Health - Thailand } \\
\text { 29,59 }\end{array}$ & $\mathrm{N}$ & $\begin{array}{l}\text { Singleplex RT-PCR with } \\
\text { fluorescent-labeled probe }\end{array}$ & $\begin{array}{l}\mathrm{N} \text { gene Ct values were positive up to } 38.12 \text {, } \\
\text { corresponding to } 15 \text { copies/reaction }\end{array}$ \\
\hline
\end{tabular}

$\mathrm{CDC}=$ Center for Disease Control and Prevention; HKU = Hong Kong University. 
decreased on the $7^{\text {th }}$ day, remaining positive until the $13^{\text {th }}$ day. In the second patient, the virus was detected on the $14^{\text {th }}$ day of symptoms in the lower and the upper respiratory tract, becoming undetectable from the $18^{\text {th }}$ to $20^{\text {th }}$ day, but coming back positive on the $25^{\text {th }}$ day ${ }^{33}$.

To ensure the best performance of the technique and to avoid RNA degradation, following the swabs collection, the samples are immersed in a transport medium/lysis buffer or a sterile saline solution ${ }^{1,29,31,34}$. Specimens should be stored at $2-8{ }^{\circ} \mathrm{C}$ for up to $72 \mathrm{~h}$ after sampling. When the test will not be performed in a short period of time, the samples should be stored at much lower temperatures, at least of $-70^{\circ} \mathrm{C}^{29,34,35}$.

Another difficulty in carrying out RT-PCR is the delay in releasing results during the pandemic ${ }^{1,10}$. The RNA extraction step, part of the diagnostic protocol, is time consuming, especially if there is no automated platform to perform this process ${ }^{36,37}$, opening loopholes for the occurrence of cross-contamination between samples and of biological hazards to the handler, if the laboratory personnel is not using proper personal protection equipment when manipulating high viral load respiratory secretions ${ }^{28,38,39}$.

Some studies have been carried out to shorten the diagnostic time using RT-PCR, and the results have shown that the RNA extraction step can be avoided in the diagnosis of COVID-19 ${ }^{36,40}$. Grant et $a l .{ }^{36}$ designed a RT-PCR to COVID-19 that do not undergo a previous RNA extraction step, and this procedure was compared with a high yield automated platform (Panther fusion Hologic) that reached $98 \%$ sensitivity and $100 \%$ specificity. The authors concluded that the RT-PCR with no previous RNA extraction step has increased the performance of the technique.

To reinforce this idea, Arumugam and Wong ${ }^{37}$, dealing with samples from influenza-suspected cases, demonstrated that the RNA extraction step is not necessary, provided that the patient's nasal swab is immersed in a viral transport medium. These results were corroborated in samples from COVID-19 patients $^{41,42}$.

In addition to the previously mentioned difficulties related to RT-PCR, specific knowledge and specialized technical training are required to perform these amplifications, aside from the high costs of reagents and thermocyclers. The occurrence of RT-PCR false-positive results are associated with handling errors and cross-contamination of samples, while false-negative results are related to the incorrect sample collection, storage and processing ${ }^{1,10}$.

\section{Enzyme Immunoassay (EIA) or Enzyme-Linked immunosorbent Assay (ELISA)}

EIA or ELISA are simple, fast and safe assays that test serum or plasma samples from infected patients. The diagnosis through ELISA is based on the detection of IgM and IgG antibodies raised to SARS-CoV-2 nucleoprotein Rp3 during the initial stages of COVID-19 disease ${ }^{1,9,10}$.

Coronavirus neutralizing antibodies target the $S$ protein (Spike) that in turn mediates the entry of the virus into the host cell. The $\mathrm{S} 1$ subunit acts on the cell binding, while the S2 subunit acts on the fusion of the viral membrane to the cell membrane $\mathrm{e}^{6,43}$.

Okba et al. ${ }^{7}$ developed serological assays for the detection of neutralizing antibodies, as well as antibodies raised to the $\mathrm{N}$ and $\mathrm{S}$ proteins, as well as subunits $\mathrm{S} 1$ and the receptor-binding domain (RBD) from the $\mathrm{S}$ protein of SARS-CoV-2 through the ELISA method. These authors demonstrated that antibodies reacted with SARS-CoV-2 proteins $\mathrm{S}, \mathrm{S} 1$ and $\mathrm{RBD}$, in addition to indicating $\mathrm{S} 1$ as the most specific antigen for the diagnosis of COVID-19. When evaluating the other domains of the protein $\mathrm{S}$, they observed that the S2 subunit is the most conserved, playing a role in the cross-reactivity with the S protein of MERS-CoV.

Reports in the literature suggest that false-positive ELISA results may occur with SARS-CoV-1 infection, as the protein $\mathrm{N}$ is extremely conserved among humaninfecting $\beta$-coronavirus ${ }^{1,10}$.

Although the ELISA for the detection of protein $\mathrm{S}$ is more specific, in patients with mild infection, the proteins $\mathrm{N}$ and RBD were more sensitive than S1, indicating the need to detect antibodies against different antigens to avoid false-negative results ${ }^{1,7}$.

The literature describes that $\operatorname{IgM}$ response to the $S$ and N SARS-CoV-1 proteins peaks four weeks after the onset of symptoms, and is no longer detected three months after the onset of symptoms, while $\operatorname{IgG}$ detection was detected around the $14^{\text {th }}$ day after the onset of symptoms, remaining detectable up to 36 months. In SARS-CoV-2, an study with 34 patients showed positivity for $\operatorname{IgM}$ and $\operatorname{IgG}$ on the $3^{\text {rd }}$ week after the onset of symptoms, with a decrease of IgM levels on the $4^{\text {th }}$ week and increase of $\operatorname{IgG}$ from the $4^{\text {th }}$ week until the $7^{\text {th }}$ week after the onset of symptoms ${ }^{44,45}$.

Guo et al $^{46}$ evaluated the humoral response against SARS-CoV-2 using an ELISA technique and plasma samples from 208 patients, 82 of whom had confirmed diagnosis of COVID-19 by RT-PCR, aside from samples of 58 probable cases according to clinical signs and symptoms, although RT-PCRs had been negative. The results indicated that the mean duration of IgM and IgA antibodies was five days, while the IgG antibodies were detected 14 days after the onset of symptoms in those with RT-PCR-confirmed infections.

These data showed that IgM detection by ELISA seems to be more efficient than RT-PCR five days after the onset of symptoms. Antibodies are known to have different temporal 
dynamics, so that a combined assessment of IgG and IgM could increase the serological diagnosis sensitivity ${ }^{1,45,46}$.

A study comparing the effectiveness of different commercially available serological tests showed $100 \%$ specificity of the Wantai SARS-CoV-2 total antibody ELISA (Beijing Wantai Biological Pharmacy Enterprise, Beijing, China), 93\% for the Euroimmun IgA ELISA (Euroimmun Medizinische Labordiagnostika, Lübeck, Germany) and $96 \%$ for the Euroimmun IgG ELISA, with sensitivities of $90 \%, 90 \%$ and $65 \%$, respectively, emphasizing the importance of combining tests raised to different antibodies ${ }^{1,47}$.

Despite the advantages of using the ELISA technique, according to the CDC-USA, serological tests should not be used for diagnosing the acute phase of the disease (within 7 days from the onset of symptoms); the serological method should be used for detecting possible previous infection in the convalescent phase, considering the period of 14 days after the onset of symptoms; for the retrospective assessment of outbreaks, epidemiologic studies, screening, diagnosis of asymptomatic patients and close contacts of confirmed cases $^{46,48,49}$.

\section{Immunochromatographic tests (rapid tests)}

Aside from the ELISA assays, immunochromatographic tests have also been studied in the context of COVID-19. It is a quick test performed by the application of a drop of the patient's sample (whole blood, serum or plasma) and a specific buffer on an immunochromatographic stick. By capillary attraction, the analyte of interest (a SARS-CoV-2 protein or peptide) binds to its specific antibody in a reaction zone and the antigen-antibody reaction will be evidenced by the formation of a colored band (colloidalgold presenting a red color or colloidal selenium presenting a blue color). This reaction should always contain a test control (band that will always appear), together with one or two other bands; one band when the test detects total antibodies anti-SARS-CoV-2 and two bands when the test differentiates IgM and IgG antibodies ${ }^{50,51}$.

Pan et al. ${ }^{2}$ showed the effectiveness of the ColloidalGold-Immunochromatographic Assay (GICA) technique for IgG and IgM anti-SARS-CoV-2 detections (Zhuhai Livzon Diagnostics Inc, Zhuhai, China), comparing results with those of RT-PCR. The sensitivity of GICA was $11.1 \%$ from the $1^{\text {st }}$ to the $7^{\text {th }}$ day after the onset of symptoms; $92.9 \%$ from the $8^{\text {th }}$ to the $14^{\text {th }}$ days and $96.8 \%$ from day 15 after the onset of symptoms.

Whole blood samples, serum and plasma samples were evaluated using the GICA technique, and the detection of $\operatorname{IgG}$ and $\operatorname{IgM}$ antibodies was consistent irrespective of the biological sample, which is an advantage of the method considering the low viral load detected in blood samples by RT-PCR ${ }^{2,31}$.

Some surveys have compared the GICA technique for the detection of IgG and IgM anti-SARS-CoV-2 with ELISA IgG and IgM, showing that both tests were 100\% specific, but ELISA showed $87 \%$ sensitivity, while GICA reached $82.4 \%$.

The Lateral Flow Immunoassay (LFIA) takes only 15 min and the analysis of 397 patients with confirmed COVID-19 diagnosis by using the LFIA IgG and IgM showed $88.66 \%$ sensitivity and $90.63 \%$ specificity. When the results obtained from the analysis of blood sampled by digital punch, venous puncture, or using serum or plasma samples were compared, the results were consistent ${ }^{52}$.

Immunochromatographic tests are a good option for diagnosing a large number of samples as it is fast, easy to perform, presenting sensitive results, allowing the identification of suspicious cases, as well as the screening and monitoring of COVID-19 progression in populations ${ }^{51}$.

\section{Microarray}

Microarray, a technique performed using small amounts of sample and reagents, is based on the detection of proteins from the specimen of interest by the recognition of antibodies immobilized on a surface, and the recognition is evidenced through the emission of a fluorescent signal that is captured and analyzed by a specific equipment ${ }^{53,54}$.

In a proteomic microarray using the genome of MN908947.3 (severe acute respiratory syndrome coronavirus 2 isolate Wuhan-Hu-1 complete genome sequence), to build the library containing 966 peptides as a reference, it was shown that the anti-SARS-CoV-1 antibodies can also detect SARS-CoV-2 proteins, providing an alternative for the diagnosis of COVID- $19^{6}$.

Wang et al. ${ }^{6}$ screened $\operatorname{IgG}$ and $\operatorname{IgM}$ antibodies in COVID-19 RT-PCR-positive patients via microarray and the technique revealed that many antibodies recognized the M, N, S, ORF1ab, ORF7a and ORF8 protein peptides. Four immune dominant epitopes were detected in more than $80 \%$ of the patients with confirmed diagnosis, namely: $\mathrm{N}$ (residue 206-210, SPARM), S (residue 816-820, SFIED) and ORF3a (residue 136-140, KNPLL; residue 176-180, SPISE). No antibodies were detected for E, ORF6 and ORF10.

Poh et al. ${ }^{55}$ analyzed 25 serum samples from patients with COVID-19 and they detected immunodominant B-cell epitopes. By depleting the antibodies directed to the epitopes S14P5, S21P2 and S14P5 + S21P2, a reduced ability to neutralize the SARS-CoV2-pseudovirus was observed. 
Experiments using the full length protein $\mathrm{S}$ revealed three main epitopes for the $\operatorname{IgM}$ antibody (816-SFIED-820; 886-WTFGA-890; 1046-GYHLM-1050) and six main epitopes for IgG antibody (26-PAYTN-30; 186-FKNLR-190; 356-KRISN-360; 456-FRKSN-460; 806-LPDPSKPSKRSFIED-820; 11196-SLIDL-1200). Within protein N, two main epitopes were selected for IgM detection (206-SPARM-210; 386-QKKQQ-390), and eight main epitopes for IgG detection (66-FPRGQ-70; 96-GGDGK-100; 166-TLPKG-170; 206-SPARM-210; 226-RLNQL-230; 256-KKPRQ-260; 316-GMSRI-320; 366-TEPKKDKKKKADETQALPQRQKKQQTVTLPA ADL-400) $)^{6}$.

Microarray studies strongly suggest that this is an effective technique for mapping the antibodies profile, monitoring the immune response and identifying candidate epitopes for the development of diagnostic tests, vaccines and even new targets for treatment. The results have also confirmed that the receptorbinding domain (RBD- residue 438-498) constitutes a good candidate for the development of neutralizing antibodies due to its action on ACE- 2 receptors ${ }^{6,55}$.

\section{CONCLUSION}

Considering all the discussed points in this mini review, we conclude that many molecular and serological techniques have been developed so far, however, there is still urgent need of safe, fast, affordable, more sensitive and accurate methods for diagnosing the infection caused by SARS-CoV-2 to control the spread of COVID-19 and to enable the development of vaccines and specific treatments.

\section{REFERENCES}

1. Singh A, Shaikh A, Singh R, Singh AK. COVID-19: from bench to bed side. Diabetes Metab Syndr. 2020;14:277-81.

2. Pan Y, Li X, Yang G, Fan J, Tang Y, Zhao J, et al. Serological immunochromatographic approach in diagnosis with SARSCoV-2 infected COVID-19 patients. J Infect. 2020;81:e28-32.

3. D'Amico F, Baumgart DC, Danese S, Peyrin-Biroulet L. Diarrhea during COVID-19 infection: pathogenesis, epidemiology, prevention and management. Clin Gastroenterol Hepatol. 2020 In Press.

4. Rothan HA, Byrareddy SN. The epidemiology and pathogenesis of coronavirus disease (COVID-19) outbreak. J Autoimmun. 2020;109:102433.

5. World Health Organization. Coronavirus disease (COVID-2019) situation report - 140. [cited 2020 Jun 18]. Available from: https://www.who.int/docs/default-source/coronaviruse/ situation-reports/20200608-covid-19-sitrep-140. pdf?sfvrsn=2f310900_2
6. Wang H, Hou X, Wu X, Liang T, Zhang X, Wang D, et al. SARSCoV-2 proteome microarray for mapping COVID-19 antibody interactions at amino acid resolution. bioRxiv. 2020 In Press.

7. Okba NM, Müller MA, Li W, Wang C, Geurts van Kessel $\mathrm{CH}$, Corman VM, et al. Severe acute respiratory syndrome Coronavirus 2: specific antibody responses in Coronavirus disease 2019 patients. Emerg Infect Dis. 2020 In Press.

8. Vaira LA, Salzano G, Deiana G, De Riu G. Anosmia and ageusia: common findings in COVID-19 patients. Laryngoscope. 2020;130:1787.

9. Xiang J, Yan M, Li H, Liu T, Lin C, Huang S, et al. Evaluation of enzyme-linked immunoassay and colloidal goldimmunochromatographic assay kit for detection of novel Coronavirus (SARS-Cov-2) causing an outbreak of pneumonia (COVID-19). medRxiv. 2020 In Press.

10. Wang Y, Wang Y, Chen Y, Qin Q. Unique epidemiological and clinical features of the emerging 2019 novel coronavirus pneumonia (COVID-19) implicate special control measures. J Med Virol. 2020;92:568-76.

11. Moein ST, Hashemian SM, Mansourafshar B, Khorram-Tousi A, Tabarsi P, Doty RL. Smell dysfunction: a biomarker for COVID-19. Int Forum Allergy Rhinol. 2020 In Press.

12. Brann D, Tsukahara T, Weinreb C, Lipovsek M, Berge KV, Gong $B$, et al. Non-neuronal expression of SARS-CoV-2 entry genes in the olfactory system suggests mechanisms underlying COVID-19-associated anosmia. bioRxiv. 2020 In Press.

13. Ahn DG, Shin HJ, Kim MH, Lee S, Kim HS, Myoung J, et al. Current status of epidemiology, diagnosis, therapeutics, and vaccines for novel Coronavirus disease 2019 (COVID-19). J Microbiol Biotechnol. 2020;30:313-24.

14. Yan CH, Faraji F, Prajapati DP, Boone CE, DeConde AS. Association of chemosensory dysfunction and Covid-19 in patients presenting with influenza-like symptoms. Int Forum Allergy Rhinol. 2020 In Press.

15. Tong ZD, Tang A, Li KF, Li P, Wang HL, Yi J-P, et al. Potential presymptomatic transmission of SARS-CoV-2, Zhejiang Province, China, 2020. Emerg Infect Dis. 2020;26:1052-4.

16. Rocklöv J, Sjödin H, Wilder-Smith A. COVID-19 outbreak on the Diamond Princess cruise ship: estimating the epidemic potential and effectiveness of public health countermeasures. J Travel Med. 2020;27:taaa030.

17. Guo YR, Cao QD, Hong ZS, Tan YY, Chen SD, Jin HJ, et al. The origin, transmission and clinical therapies on coronavirus disease 2019 (COVID-19) outbreak: an update on the status. Mil Med Res. 2020;7:11.

18. Lim J, Jeon S, Shin HY, Kim MJ, Seong YM, Lee WJ, et al. Case of the index patient who caused tertiary transmission of Coronavirus disease 2019 in Korea: the application of lopinavir/ritonavir for the treatment of COVID-19 pneumonia monitored by quantitative RT-PCR. J Korean Med Sci. 2020;35:e79. 
19. Pan Y, Yu X, Du X, Li Q, Li X, Qin T, et al. Epidemiological and clinical characteristics of 26 asymptomatic SARS-CoV-2 carriers. J Infect Dis. 2020;221:1940-7.

20. Zhu J, Zhong Z, Li H, Ji P, Pang J, Li B, et al. CT imaging features of 4,121 patients with COVID-19: a meta-analysis. J Med Virol. 2020;92:891-902.

21. Zhang J, Liu P, Wang M, Wang J, Chen J, Yuan W, et al. The clinical data from 19 critically ill patients with coronavirus disease 2019: a single-centered, retrospective, observational study. Z Gesundh Wiss. 2020 In Press.

22. Tan C, Huang Y, Shi F, Tan K, Ma Q, Chen Y, et al. C-reactive protein correlates with $\mathrm{CT}$ findings and predicts severe COVID-19 early. J Med Virol. 2020;92:856-62.

23. Li X, Geng M, Peng Y, Meng L, Lu S. Molecular immune pathogenesis and diagnosis of COVID-19. J Pharm Anal. 2020;10:102-8.

24. Ye Q, Wang B, Mao J. The pathogenesis and treatment of the 'cytokine storm' in COVID-19. J Infect. 2020;80:607-13.

25. Mehta P, McAuley DF, Brown M, Sanchez E, Tattersall RS, Manson JJ. COVID-19: consider cytokine storm syndromes and immunosuppression. Lancet. 2020;395:1033-4.

26. Wang C, Horby PW, Hayden FG, Gao GF. A novel coronavirus outbreak of global health concern. Lancet. 2020;395:470-3.

27. Corman VM, Landt O, Kaiser M, Molenkamp R, Meijer A, Chu DK, et al. Detection of 2019 novel coronavirus (2019-nCoV) by real-time RT-PCR. Euro Surveill. 2020;25:2000045.

28. Wang M, Wu Q, Xu W, Qiao B, Wang J, Zheng H, et al. Clinical diagnosis of 8274 samples with 2019-novel coronavirus in Wuhan. medRxiv. 2020 In Press.

29. World Health Organization. Molecular assays to diagnose COVID-19: summary table of available protocols. [cited 2020 Jun 18]. Available from: https://www.who.int/publications $/ \mathrm{m} /$ item/molecular-assays-to-diagnose-covid-19-summary-tableof-available-protocols

30. Zhang Y, Odiwuor N, Xiong J, Sun L, Nyaruaba RO, Wei H, et al. Rapid molecular detection of SARS-CoV-2 (COVID-19) virus RNA using colorimetric LAMP. medRxiv. 2020 In Press.

31. Sridhar S, Forrest S, Kean I, Young J, Scott JB, Maes M, et al. A blueprint for the implementation of a validated approach for the detection of SARS-Cov2 in clinical samples in academic facilities. bioRxiv. 2020 In Press.

32. Yang Y, Yang M, Shen C, Wang F, Yuan J, Li J, et al. Evaluating the accuracy of different respiratory specimens in the laboratory diagnosis and monitoring the viral shedding of 2019-nCoV infections. medRxiv. 2020 In Press.

33. Tahamtan A, Ardebili A. Real-time RT-PCR in COVID-19 detection: issues affecting the results. Expert Rev Mol Diagn. 2020;20:453-4.

34. Centers for Disease Control and Prevention. Interim guidelines for collecting, handling, and testing clinical specimens for COVID-19. [cited 2020 Jun 17]. Available from: https:// www.cdc.gov/coronavirus/2019-ncov/lab/guidelines-clinicalspecimens.html?CDC_AA_refVal=https $\% 3 \mathrm{~A} \% 2 \mathrm{~F} \% 2 \mathrm{Fwww}$. cdc.gov\%2Fcoronavirus\%2F2019-ncov\%2Fguidelinesclinical-specimens.html

35. Sitarska D, Ługowska A. Laboratory diagnosis of the NiemannPick type $\mathrm{C}$ disease: an inherited neurodegenerative disorder of cholesterol metabolism. Metab Brain Dis. 2019;34:1253-60.

36. Grant PR, Turner MA, Shin GY, Nastouli E, Levett LJ. Extractionfree COVID-19 (SARS-CoV-2) diagnosis by RT-PCR to increase capacity for national testing programmes during a pandemic. bioRxiv. 2020 In Press.

37. Arumugam A, Wong S. The potential use of unprocessed sample for RT-qPCR detection of COVID-19 without an RNA extraction step. bioRxiv. 2020 In Press.

38. Schmid-Burgk JL, Li D, Feldman D, Słabicki M, Borrajo J, Strecker J, et al. LAMP-Seq: population-scale COVID-19 diagnostics using a compressed barcode space. bioRxiv. 2020 In Press.

39. Aslanzadeh J. Preventing PCR amplification carryover contamination in a clinical laboratory. Ann Clin Lab Sci. 2004;34:389-96.

40. Merindol N, Pépin G, Marchand C, Rheault M, Peterson C, Poirier A, et al. Optimization of SARS-CoV-2 detection by RT-QPCR without RNA extraction. bioRxiv. 2020 In Press.

41. Beltrán-Pavez C, Márquez CL, Muñoz G, Valiente-Echeverría F, Gaggero A, Soto-Rifo R, et al. SARS-CoV-2 detection from nasopharyngeal swab samples without RNA extraction. bioRxiv. 2020 In Press.

42. Bruce EA, Huang ML, Perchetti GA, Tighe S, Laaguiby P, Hoffman JJ, et al. Direct RT-qper detection of SARS-cov-2 RNA from patient nasopharyngeal swabs without an RNA extraction step. bioRxiv. 2020 In Press.

43. Wang C, Li W, Drabek D, Okba NM, van Haperen R, Osterhaus $\mathrm{AD}$, et al. A human monoclonal antibody blocking SARSCoV-2 infection. Nat Commun. 2020;11:2251.

44. Siracusano G, Pastori C, Lopalco L. Humoral immune responses in COVID-19 patients: a window on the state of the art. Front Immunol. 2020;11:1049.

45. Huang AT, Garcia-Carreras B, Matt DT, Hitchings BY, Katzelnick L, Rattigan SM, et al. A systematic review of antibody mediated immunity to coronaviruses: antibody kinetics, correlates of protection, and association of antibody responses with severity of disease. medRxiv. 2020 In Press.

46. Guo L, Ren L, Yang S, Xiao M, Chang D, Yang F, et al. Profiling early humoral response to diagnose novel Coronavirus disease (COVID-19). Clin Infect Dis. 2020 In Press.

47. Lassaunière R, Frische A, Harboe ZB, Nielsen AC, Krogfelt KA, Jørgensen CS. Evaluation of nine commercial SARS-CoV-2 immunoassays. medRxiv. 2020 In Press.

48. Centers for Disease Control and Prevention. Overview of testing for SARS-CoV-2. [cited 2020 Jun 17]. Available from: https:// 
www.cdc.gov/coronavirus/2019-nCoV/hcp/clinical-criteria. html

49. Hong KH, Lee SW, Kim TS, Huh HJ, Lee J, Kim SY, et al. Guidelines for laboratory diagnosis of Coronavirus disease 2019 (COVID-19) in Korea. Ann Lab Med. 2020;40:351-60.

50. Watson ID. Clinical diagnosis: chromatography. In: Poole C, Cooke M, editors. Encyclopedia of separation science. London: Academic Press; 2000. p.2484-90.

51. Chen Z, Zhang Z, Zhai X, Li Y, Lin L, Zhao H, et al. Rapid and sensitive detection of anti-SARS-CoV-2 IgG, using lanthanidedoped nanoparticles-based lateral flow immunoassay. Anal Chem. 2020;92:7226-31.

52. Li Z, Yi Y, Luo X, Xiong N, Liu Y, Li S, et al. Development and clinical application of a rapid IgM-IgG combined antibody test for SARS-CoV-2 infection diagnosis. J Med Virol. 2020 In Press.

53. Sutandy FX, Qian J, Chen CS, Zhu H. Overview of protein microarrays. Curr Protoc Protein Sci. 2013;72:2711-6.

54. Chen Z, Dodig-Crnković T, Schwenk JM, Tao S. Current applications of antibody microarrays. Clin Proteomics. 2018;15:7
55. Poh CM, Carissimo G, Wang B, Amrun SN, Lee CY, Chee RS, et al. Potent neutralizing antibodies in the sera of convalescent COVID-19 patients are directed against conserved linear epitopes on the SARS-CoV-2 spike protein. bioRxiv. 2020 In Press.

56. Niu P, Lu R, Zhao, L, Wang H, Huang B, Ye F, et al. Three novel real-time RT-PCR assays for detection of COVID-19 virus. China CDC Wkly. 2020. [cited 2020 Jun 17]. Available from: http://weekly.chinacdc.cn/en/article/id/56e46c21-502e-4811866e-568121359510

57. Vogels CB, Brito AF, Wyllie AL, Fauver JR, Ott IM, Kalinich $\mathrm{CC}$, et al. Analytical sensitivity and efficiency comparisons of SARS-COV-2 qRT-PCR assays. medRxiv. 2020 In Press.

58. Pang J, Wang MX, Ang IY, Tan SH, Lewis RF, Chen JI, et al. Potential rapid diagnostics, vaccine and therapeutics for 2019 novel Coronavirus (2019-nCoV): a systematic review. J Clin Med. 2020;9:623.

59. Jung YJ, Park GS, Moon JH, Ku K, Beak SH, Kim S, et al. Comparative analysis of primer-probe sets for the laboratory confirmation of SARS-CoV-2. bioRxiv. 2020 In Press. 